\title{
Share Valuation Methods And Data Source-Based Accounting In An Emerging Stock Market: The Case Of The Kuwaiti Stock Market
}

\author{
Hesham. I. Almujamed, Public Authority for Applied Education and Training, Kuwait \\ Suzanne G. M. Fifield, University of Dundee, U.K. \\ David .M. Power, University of Dundee, U.K.
}

\begin{abstract}
This paper uses a questionnaire survey to investigate share valuation methods and the sources of information employed by Kuwaiti investors; it compares the appraisal techniques and the sources of information employed by Kuwaiti investors to those used in other developed and emerging stock markets.

The findings suggest that Kuwaiti investors behave like their counterparts in other stock markets; fundamental analysis is the main appraisal technique used by investors; technical analysis and risk analysis are ranked second and third, respectively. However, the usage of technical and risk analysis is much higher in Kuwait. Further, quarterly and annual corporate reports as well as newspapers, the Kuwait Stock Exchange (KSE) website, and charts are commonly studied by investors when valuing Kuwaiti shares. By contrast, communication with company management is not common since executives are usually unwilling to discuss their firm's performance with investors.
\end{abstract}

Keywords: Share Valuations; Source of Information; Accounting Information; Emerging Markets; Kuwait

\section{INTRODUCTION}

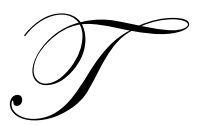

his study explores the share valuation methods used by Kuwaiti investors through the use of a questionnaire survey. In particular, the research seeks to answer a number of questions that have not yet been addressed in the accounting and finance literature about an emerging market country like Kuwait. The main research question focuses on the specific appraisal techniques used by Kuwaiti investors. Additionally, questions concentrate on details regarding the sources of information employed by Kuwaiti investors when making investment decisions concerning securities traded on the Kuwait Stock Exchange (KSE). These questions are examined against the backdrop of ongoing changes being made to the operation of the Kuwaiti stock market.

To date, the research in this area is scarce; very little is known about how Kuwaiti investors evaluate shares when making equity investment decisions. Very few studies have sought out the views of different types of Kuwaiti investors on the issues being explored here. While a number of researchers have conducted market-based studies and ascertained user views on various aspects of Kuwaiti company reporting (Naser et al., 2003; Al-Yaqout, 2006), only Almujamed et al. (2010) have addressed the question of which share valuation approaches and data sources are primarily used by Kuwaiti investors. In particular, Almujamed et al. conducted semi-structured interviews with eight institutional investors, six technical analysts, and two investment analysts in July of 2008. However, their investigation focused mainly on the role of technical analysis in the KSE and not the different approaches of investors to share appraisal. 
The current study is more comprehensive, as it investigates all the different appraisal techniques that investors may employ (fundamental, technical, and risk analyses) as well as exploring the various sources of information used by key investors and advisors for the KSE, such as fund managers, individual investors, analysts and stockbrokers. The results of the study are then contrasted with the findings from investigations of the same issues in other developed and emerging countries (Arnold et al., 1984; Pike et al., 1993; Al Abdulqader et al., 2007; Wang et al., 2007; Tijjani, 2008).

The remainder of the paper is structured as follows. Section 2 provides an overview of the KSE; Section 3 reviews the relevant literature on the topic; Section 4 outlines the details of the sample and describes the research method used; Section 5 discusses the results from the questionnaire. Finally, Section 6 offers the conclusions for the study and also discusses its limitations as well as opportunities for future research.

\section{AN OVERVIEW OF THE KUWAITI STOCK MARKET}

The Kuwaiti stock market is the third largest exchange in the Middle East and North Africa in terms of market capitalisation; its market capitalisation totalled \$113.9 billion on 31 December 2010 (Arab Monetary Fund, 2010). Further, the country of Kuwait is currently the fourth largest exporter of oil in the world and holds $9.5 \%$ of the world's crude oil reserves (OPEC Annual Statistical Bulletin, 2009). Oil revenues account for approximately 93\% of State revenues and make up over 54\% of the nation's total Gross Domestic Product (Central Bank of Kuwait, 2009). Therefore, it is not surprising that Kuwait has attracted the attention of international investors (Almujamed, 2011). For example, Mark Mobius, the founder of the Templeton Emerging Markets Fund, indicated that the Kuwaiti economy had the potential for significant economic growth after 2007 (Mobius, 2008).

Historically, Kuwait has the oldest and most structured stock market in the Gulf region (Almujamed, 2011). Al-Yaqout (2006) states that although the first KSE was not formally established until 1977, share trading occurred long before that date; trading began in the early 1950s, following an initial public offering by the National Bank of Kuwait. The government then undertook a privatisation programme between 1994 and 1999; 2,499 million shares in 30 companies were sold to the public for KD901.6 million ${ }^{1}$ (Abul, 2005). Further, new regulations were introduced to increase public transparency of the listed firms and protect the rights of all shareholders. ${ }^{2}$ In addition, the KSE allowed foreign nationals to own up to $100 \%$ of any company listed on the KSE (KSE, 2011). Moreover, the profits earned by foreign investors on transactions in the Kuwait stock market, either directly via their own purchase and sales of shares or indirectly through investment funds are not subject to taxation (Standard and Poor's, 2009).

Currently, the KSE has 230 listed companies, which operate in eight different sectors (Aljoman Centre for Economic Consultancy, 2011). The exchange has a number of market-makers, and 14 brokers registered in the country (KSE, 2011). The KSE has only one physical location in Kuwait City- a main trading hall surrounded by 14 brokerage offices that provide services to investors (Almujamed, 2011). ${ }^{3}$ By contrast, the stock markets in developed countries like the U.S. are geographically diverse and transact trades with a large number of brokers who operate in several locations. Thus, one might expect that KSE investors would use different investment techniques than their Western counterparts since all of the KSE market facilities are in one geographic location and informal communications as well as rumours also circulate among market participants (Al-Loughani, 1995; Almujamed, 2011). Not surprisingly, academics have noted that security prices for the Kuwaiti stock market behave differently from their counterparts in developed stock markets; these studies have shown that share price changes are often the result of competition among rival business groups, the political situation in the Gulf region, and the size as well as the distribution of government spending (Al-Loughani, 1995; Al-Loughani and Moosa, 1999; Al-Yaqout, 2006; Abumustafa, 2007; Almujamed, 2011). Further, family networks are possibly stronger in Kuwait than in the

\footnotetext{
${ }^{1}$ The 1999 exchange rate of the KD against the U.S. dollar was then KD 0.3033/US\$.

${ }^{2}$ In 1998, the KSE obligated all listed companies to publish financial statements on a quarterly basis, and in 2007 , they compelled quoted companies to hold their Annual General Meeting (AGM) within 45 days from the date of the approval of their annual reports by the KSE. Quoted companies must also distribute cash and/or share dividends within 10 days from the date of the approval of such disbursements by the AGM (KSE, 2008: Market Committee, Decision No. 4 for Year 2007).

${ }^{3}$ According to Almujamed (2011), only a minority of investors use online trading; he argues that the regulators of the KSE are unhappy with the current situation of the trading hall in the exchange as rumours circulate among investors.
} 
developed countries, a characteristic which supports the argument that equity investors in Kuwait may place less emphasis on annual reports and articles about companies in the financial press; information may instead be obtained from informed family members rather than from other published or unpublished sources (Al-Shamali, 1989).

\section{LITERATURE REVIEW}

Most of the academic literature from the developed as well as other emerging market countries indicates that fundamental analysis is the main method employed when valuing ordinary shares (Arnold and Moizer, 1984; Arnold et al., 1984; Pike et al., 1993; Al Abdulqader et al., 2007; Wang et al., 2007; Tijjani, 2008; Almujamed et al., 2010). Studies also note that technical and risk analyses rank second and third in importance, respectively, in the investment decision-making process. For example, Arnold et al. (1984) discover that fundamental analysis is employed by $92.2 \%$ of financial analysts in the U.S. and the U.K., while technical analysis is only "sometimes" used by $41.5 \%$ of their sample; risk analysis is only used by $21.1 \%$ and on an infrequent basis.

In one of the first detailed investigations on this topic, Arnold and Moizer (1984) interviewed six U.K. analysts and discovered that the analysts typically forecast Earning Per Share (EPS) for one to two years and multiply this predication by an appropriate P/E multiple. The results of the studies in different developed countries over various time periods have confirmed Arnold and Moizer's (1984) pioneering findings. Investigations conducted in Germany (Pike et al., 1993) indicate that fundamental analysis in general and the P/E approach in particular characterises the equity valuation activities of most investors; indeed, the Discounted Cash Flow (DCF) approach is hardly ever used. Investors rate the Profit and Loss Account and Balance Sheet as two important sources of information for their fundamental valuation analysis. ${ }^{4}$ Arnold and Moizer (1984) note that the technical analyses may also be used by analysts who concentrate on a company's fundamentals to time the purchase or sale of a share. They suggest that such technical a approach complements the fundamental analysis which is undertaken. AlAbdulqader et al. (2007) and Almujamed et al. (2010) support this conclusion for emerging markets; they believe that charts can help investors to select shares because the level of disclosure and the degree of transparency in these countries is low; investors can study charts on prices and volume because that information is more readily available and possibly even more reliable than the financial information supplied in company annual reports. Lovell-Green et al. (1986) argue that the presumed inefficiency of emerging markets for investors could explain the popularity of technical analysis as a valuation method in these markets. Risk analysis is also seen as an important technique, particularly in emerging markets. Harvey (1995) states that the returns on equities in emerging countries remain volatile. Therefore, these shares will exhibit higher risk relative to their counterparts in the developed countries; it is not surprising, therefore, that risk analysis might be more pronounced in emerging markets than in developed markets.

Surprisingly, however, the dominance of the fundamental approach to share valuation which characterises developed market is also detected when surveys on the emerging stock markets are conducted. In one of the first such investigations of the topic within an ESM, Al Abdulqader et al. (2007) found that practically all of the 34 interviewees and most of the respondents to their questionnaire survey $(70.8 \%)$ used fundamental analysis to value Saudi shares. A majority attempted to forecasts a company's earnings and multiplied this prediction by a suitable P/E ratio; the respondents to the survey forecast mainly Profit and Loss Account and Balance Sheet information when conducting their analyses.

Similar empirical findings have been documented for China (Wang et al., 2007), Nigeria (Tijjani et al., 2009) and the countries in Central and Eastern Europe (Middleton et al., 2007). To date, the only study on this topic in Kuwait was undertaken by Almujamed et al. (2010). ${ }^{5}$ Based on 16 interviews, that study found that Kuwaiti investors like those in other developed and emerging markets mainly employed fundamental analysis to value ordinary shares; technical and risk analyses were rated second and third, respectively. The P/E ratio approach was

\footnotetext{
${ }^{4}$ Subtle variations in the sources of information studied by analysts have also been uncovered in country-specific investigations of this issue. For instance, when Pike et al. (1993), Barker (1999), and Clatworthy (2005) surveyed UK analysts several years after Arnold and Moizer's pioneering study in 1984, they found that discussions with company personnel had become more important.

${ }^{5}$ Most of the limited studies of the KSE have tested the weak-form of the EMH (Butler \& Malaikah, 1992; Al-Loughani, 1995).
} 
commonly used in Kuwait, while the DCF method was rarely employed by the research participants. The Balance Sheet and the Profit and Loss Account were given the same top rating by interviewees, while the Cash Flow statement was ranked third in order of importance.

In their analysis, Almujamed et al. highlighted that technical analysis was commonly used among Kuwaiti participants; they argued that the interviewees used technical analysis in all of their short-term investment decisions, particularly when timing entry and exit points; the type of technical analysis employed involved a mixture of trends and pattern seeking. Moreover, the moving average technique was a popular strategy among investors, and the filter rule approach is not used. In addition, the researchers noted that technical analysts in Kuwait behaved differently from their counterparts in developed stock markets; the Kuwaiti analysts initially scanned a firm's profitability before looking at the firm's charts. Further, they all followed the trading activities of large investors when they bought and sold shares on the KSE.

Almujamed (2011) suggested that investors in Kuwait were cautious about the risks that they faced, such as the lack of timely information and the absence of rules on insider trading, the prevalence of rumours, and the concern about political risk in Kuwait as well as the rest of the Gulf region; they suggested that these factors explained the high levels of volatility in share returns for the KSE.

Almujamed et al. also noted that the interviewees used both public and private information to evaluate their equity investments, including corporate reports, news, charts, insider information, and discussions with company staff; these sources were all rated highly by Almujamed et al. interviewees. The current study builds on Almujamed et al.'s (2011) findings for Kuwait. Instead of interviews, we use a questionnaire survey to ascertain the views of a large sample regarding equity valuation methods and information sources used by investors. Further, a mix of investors is consulted in the current paper; Almujamed et al. (2011) only talked to a small number of analysts (14 investors and two analysts). Finally, the views of a broad range of investors on several investment approaches appears in the current paper; unlike Almujamed et al. (2011), we do not concentrate on the role of technical analysis for chartists.

\section{RESEARCH METHOD}

A questionnaire was developed from the previous literature that investigated share valuation methods used by investors (e.g. Arnold \& Moizer, 1984; Pike et al., 1993; Al-Abdulqader et al., 2007; Tijjani et al., 2009; Almujamed et al., 2010). In particular, this research builds on the Almujamed et al.'s (2010) findings for the appraisal techniques employed and the information sources studied by Kuwaiti investors. This study seeks to determine whether the Almujamed et al. interview results and other findings are generalisable to a larger sample of different investors. An initial draft of the questionnaire was piloted with three analysts, two fund managers and four individual investors. Based on their comments and input, the questionnaire was amended several times. Specifically, a number of these individuals who reviewed the questionnaire suggested that certain terms needed more explanation, in particular fundamental analysis, technical analysis and risk analysis. Explanations were then added to the questionnaire to avoid any ambiguity of meaning for the participants.

Based on discussions with those who piloted the questionnaire and consultations with academics and stockbrokers, a decision was made to distribute the questionnaire by hand rather than via the postal mail system; within the context of Kuwait, it was felt that the response rate from using the post system would have been lower. Not enough addresses could be obtained for posting large numbers of questionnaires particularly those for fund managers and individual investors. In addition, the culture of Kuwait stresses the importance of power of contanct when dealing with series individual; asking a stranger to divulge information without any introduction from a mutual acquaintance is frowned upon in Kuwait. Therefore, personal contact was the method used to distribute the questionnaires. This decision allowed the researchers to address any issues immediately that participants had about the content of the questionnaire. In general, no issues were raised when the questionnaire was distributed; the only exception related to the question about the nature of a respondent's investment in the KSE. Some eight individuals 
indicated they had been short-term speculators, but had become more longer term investors since $2008 .{ }^{6}$ The change occurred because their portfolios of KSE equities had declined significantly during the summer of 2008 .

The survey questionnaire targeted key players in the Kuwaiti stock market: analysts, fund managers, individual investors, and stockbrokers. The choice of groups was influenced by the literature and the responses from the early piloting of the questionnaire. The main trading hall for the KSE was the "research site" for surveying both individual investors and stockbrokers. Unlike London, New York, and other stock markets in the more developed countries, most small Kuwaiti investors will walk into brokerage offices at the KSE hall to buy or sell securities. Such a situation would justify selecting the KSE building as the field site for distributing questionnaires (Almujamed et al., 2010). All 14 brokerage firms that are registered in Kuwait and operate in the main trading unit of the KSE were targeted. ${ }^{7}$ Those individual investors present in the main trading hall of the KSE were asked to complete questionnaires. This strategy for targeting individual investors was proposed by those who participated in the pilot survey; they suggested that individuals who frequented the trading hall of the KSE were active investors and often exposed to corporate news, tips, advice from friends, and current rumours circulating in the stock market. Friends and relatives of the analysts and fund managers helped distribute the questionnaires at the offices where they worked.

The data were collected between January and March of 2010. The vast majority of investor questionnaires were collected on the day they were distributed while analysts, fund managers and stockbroker were given specific times when a researcher would return to collect the survey instruments. Some had to be reminded and visited three times. This process was successful in ensuring that the survey response rate was higher than that achieved if a postal service had been used.

Table 1: Respondents to the Questionnaire Survey

\begin{tabular}{|c|c|c|c|c|c|c|c|c|c|c|c|}
\hline \multirow[t]{2}{*}{ Part A : Position } & \multicolumn{3}{|c|}{ Distributed Questionnaire } & \multicolumn{4}{|c|}{ Responses } & \multicolumn{4}{|c|}{ Useable Responses } \\
\hline & No. & \multicolumn{2}{|c|}{$\%$} & \multicolumn{2}{|c|}{ No. } & \multicolumn{2}{|c|}{$\%$} & \multicolumn{2}{|c|}{ No. } & \multicolumn{2}{|c|}{$\%$} \\
\hline Fund Mangers & 30 & \multicolumn{2}{|c|}{100.0} & \multicolumn{2}{|c|}{17} & \multicolumn{2}{|c|}{56.7} & \multicolumn{2}{|c|}{13} & \multicolumn{2}{|c|}{76.5} \\
\hline $\begin{array}{l}\text { Individual } \\
\text { Investors }\end{array}$ & 130 & \multicolumn{2}{|c|}{100.0} & \multicolumn{2}{|c|}{84} & \multicolumn{2}{|c|}{64.6} & \multicolumn{2}{|c|}{79} & \multicolumn{2}{|c|}{94.0} \\
\hline Analysts & 70 & \multicolumn{2}{|c|}{100.0} & \multicolumn{2}{|c|}{42} & \multicolumn{2}{|c|}{60.0} & \multicolumn{2}{|c|}{38} & \multicolumn{2}{|c|}{90.5} \\
\hline Stockbrokers & 60 & \multicolumn{2}{|c|}{100.0} & \multicolumn{2}{|c|}{24} & \multicolumn{2}{|c|}{40.0} & \multicolumn{2}{|c|}{24} & \multicolumn{2}{|c|}{100.0} \\
\hline Others & 30 & \multicolumn{2}{|c|}{100.0} & \multicolumn{2}{|c|}{30} & \multicolumn{2}{|c|}{100.0} & \multicolumn{2}{|c|}{0} & \multicolumn{2}{|c|}{0.0} \\
\hline Total & 320 & \multicolumn{2}{|c|}{100.0} & \multicolumn{2}{|c|}{197} & \multicolumn{2}{|c|}{61.5} & & & & .1 \\
\hline Part: B & & & & & & & & & & & \\
\hline & & All Pe & ipants & & & & & & & & B \\
\hline Statement & & $N$ & $\%$ & $N$ & $\%$ & $N$ & $\%$ & $N$ & $\%$ & $N$ & $\%$ \\
\hline $\begin{array}{l}\text { Total number of } r \\
154 \text { useable respon }\end{array}$ & relative to & 154 & 100.0 & 13 & 8.4 & 79 & 51.2 & 38 & 24.7 & 24 & 15.6 \\
\hline
\end{tabular}

Note: This table shows the responses to the questionnaire survey based on such participant's job. Part A reports the number and percentage of distributed and useable responses in the questionnaire survey while Part B indicates the number and the percentage of responses useable based on participant's job. The participants include Fund Mangers (FM); (ii) Individual Investors (IV); (iii) Analysts (AN); and (iv) Stockbrokers (SB); Others relates to employees of the KSE and Kuwait Clearing House. $N$ denotes the number of participants for all and each group respectively.

\footnotetext{
6 The stock prices for most of the Kuwait- quoted companies on the KSE fell sharply in 2008 as the market was affected by the decline of global stock markets (Almujamed, 2011). Several individual investors reported that the vast majority of their investments are now long-term investments, and only a small part of their portfolio is used for speculating; they argued that they did not have any other option until the stock market recovered, and they would suffer capital losses if they sold their shares at current prices.

${ }^{7}$ Stockbrokers in Kuwait are not officially involved in share valuation; they do not analyse shares, manage funds, or offer recommendations. They just execute orders; however, most do trade unofficially, manage funds, and provide recommendations to their friends and relatives (Almujamed, 2011). However, a discussion with those who took part in the pilot and the academics recommended the inclusion of stockbrokers in the sample, as some stockbrokers are active traders and thus more knowledgeable about investment decisions and the sources of information used in the KSE.
} 
Table 1 indicates that 154 of 320 useable questionnaires (a response rate of $48.1 \%$ ) were collected and analysed in the reminder of this paper (see Part A of Table 1). ${ }^{8}$ A review of Part B of Table 1 shows that $51.2 \%$ of respondents were individual investors, which is not surprising, as access to individual investors in the trading hall of the KSE was easier than access to other participant groups.

\section{RESULTS AND DISCUSSIONS}

Table 2 summarizes the background information on the research participants and demonstrates that most of the respondents were highly educated and had either a formal qualification or training in the accounting and finance areas. Analysts and fund managers were the most educated groups; a majority had at least a Bachelor's degree, and a sizeable minority held a Master's degree. These demographics suggest that analysts and fund managers may be more knowledgeable about securities analysis than were investors. Most participants (69.1\%) gained their academic qualifications in Kuwait, and a small proportion had studied in the U.K. (5.3\%), the USA (11.8\%) or in other countries $(13.8 \%))^{9}$ A majority of the participants $(80.1 \%)$ had more than five years of experience analysing or trading equities on the KSE. These characteristics strongly suggest that the respondents were knowledgeable about the research area and their opinions well worth examining.

Table 2: Background Information on the Participants

\begin{tabular}{|c|c|c|c|c|c|c|c|c|c|c|c|}
\hline \multirow[t]{2}{*}{ Statements } & \multirow[t]{2}{*}{ Choice of Answer } & \multicolumn{2}{|c|}{ All } & \multicolumn{2}{|c|}{ FM } & \multicolumn{2}{|c|}{ IV } & \multicolumn{2}{|c|}{$\mathbf{A N}$} & \multicolumn{2}{|c|}{ SB } \\
\hline & & $N$ & $\%$ & $N$. & $\%$ & $N$. & $\%$ & $N$. & $\%$ & $N$ & $\%$ \\
\hline \multirow{2}{*}{ Background } & Financial & 106 & 68.8 & 13 & 100.0 & 43 & 54.4 & 31 & 81.6 & 19 & 79.2 \\
\hline & Non-Financial & 48 & 31.2 & 0 & 0.0 & 36 & 45.6 & 7 & 18.4 & 5 & 20.8 \\
\hline \multirow{5}{*}{$\begin{array}{l}\text { Education } \\
\text { Qualifications }\end{array}$} & Less than Diploma & 99 & 5.9 & 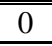 & 0.0 & 3 & 3.8 & 1 & 2.6 & $\overline{55}$ & 21.7 \\
\hline & Diploma & 29 & 19.0 & 0 & 0.0 & 21 & 26.6 & 3 & 7.9 & 5 & 21.7 \\
\hline & Bachelors & 80 & 52.3 & 8 & 61.5 & 41 & 51.9 & 20 & 52.6 & 11 & 47.8 \\
\hline & Master & 33 & 21.6 & 5 & 38.5 & 12 & 15.2 & 14 & 36.8 & 2 & 8.7 \\
\hline & Doctorate & 2 & 1.3 & 0 & 0.0 & 2 & 2.5 & 0 & 0.0 & 0 & 0.0 \\
\hline \multirow{4}{*}{$\begin{array}{l}\text { Country of } \\
\text { Education }\end{array}$} & Kuwait & 105 & 69.1 & 10 & 76.9 & 59 & 74.7 & 21 & 55.3 & 15 & 68.2 \\
\hline & U.K. & 8 & 5.3 & 0 & 0.0 & 6 & 7.6 & 2 & 5.3 & 0 & 0.0 \\
\hline & USA & 18 & 11.8 & 1 & 7.7 & 9 & 11.4 & 5 & 13.2 & 3 & 13.6 \\
\hline & Other & 21 & 13.8 & 2 & 15.4 & 5 & 6.3 & 10 & 26.3 & 4 & 18.2 \\
\hline \multirow{3}{*}{$\begin{array}{l}\text { Years of } \\
\text { Experience }\end{array}$} & Less than 5 years & 58 & 38.4 & 4 & 30.8 & 28 & 36.4 & 16 & 42.1 & 10 & 43.5 \\
\hline & $\begin{array}{l}\text { Between } 5 \text { and } 10 \\
\text { years }\end{array}$ & 63 & 41.7 & 5 & 38.5 & 36 & 46.8 & 15 & 39.5 & 7 & 30.4 \\
\hline & More than 10 years & 30 & 19.9 & 4 & 30.8 & 13 & 16.9 & 7 & 18.53 & 6 & 26.1 \\
\hline
\end{tabular}

Note: The table presents background details for the research participants. Specifically, it reports statistics on the academic background, education qualification, country of education and experience of the respondents. The percentage of these frequencies are based on the number of responses relative to the total number of questionnaires with replies for each statement; 153 , 152 and 151 answers were available for education qualification, country of education and years of experience respectively.

Details on the level and type of investment undertaken by the participants were also ascertained; their responses are summarized in Table 3. An analysis of this table shows that fund managers invested larger sums in the KSE when compared to other participant groups. This result was expected since fund managers administer funds on behalf of clients. In addition, a visual inspection of Table 3 shows that only a minority of respondents (26.4\%)

\footnotetext{
${ }^{8}$ In fact, 197 of the 320 distributed questionnaires were returned. However, 43 of the participants who filled questionnaires were excluded from the analysis, reducing the number of useable responses to 154 . This decision was made because 13 respondents left most of the questions unanswered and another 30 respondents were not involved in share valuation and did not invest at all in the KSE. These respondents were employees of the KSE and the Kuwait Clearing House (KCH); some worked in the filing department for listed companies of the KSE, and others worked as accountants at the $\mathrm{KCH}$. Therefore, a decision was made to omit these responses.

${ }^{9}$ Other respondents gained academic qualifications from other countries, such as Egypt, India, Jordan, and Lebanon. This different background enriched the research and may have generated different results on the appraisal techniques used in the Kuwaiti stock market.
} 
invested for long-term horizons of more than two years. Indeed, the majority of fund managers and stockbrokers held shares for less than two years; most analysts and individual investors had similar investment horizons and held their securities for less than 12 months. ${ }^{10}$ These findings suggest that speculation was the dominant approach to investing among all the respondents in the current research; they support the earlier results of Almujamed (2011), namely that investors in Kuwait are predominantly short term in outlook (Al-Loughani, 1995; Al-Loughani \& Moosa, 1999; Abumustafa, 2007; Almujamed, 2011).

In addition, Table 3 indicates that most individuals, analysts and stockbrokers are small investors as their investments did not exceed KD50,000. ${ }^{11}$ Moreover, a sizeable majority do consider shares from a variety of sectors, especially the fund managers where only $15.8 \%$ focus on a specific industry. Finally, an analysis of all the responses indicates that the typical investor has less than 11 securities in a portfolio; again, fund managers were the exception since their portfolios tended to include shares for a larger number of firms.

Table 3: Investment Characteristics of Participants Respondents

\begin{tabular}{|c|c|c|c|c|c|c|c|c|c|c|c|}
\hline \multirow[t]{2}{*}{ Statements } & \multirow[t]{2}{*}{ Choice of Answer } & \multicolumn{2}{|c|}{ All } & \multicolumn{2}{|c|}{ FM } & \multicolumn{2}{|c|}{ IV } & \multicolumn{2}{|c|}{$\mathbf{A N}$} & \multicolumn{2}{|c|}{ SB } \\
\hline & & $N$ & $\%$ & $N$ & $\%$ & $N$ & $\%$ & $N$ & $\%$ & $N$ & $\%$ \\
\hline \multirow{5}{*}{$\begin{array}{l}\text { Average } \\
\text { amount } \\
\text { invested }\end{array}$} & Less than KD 10,000 & 25 & 19.2 & 0 & 0.0 & 16 & 22.2 & 8 & 23.5 & 1 & 25.0 \\
\hline & $\begin{array}{l}\text { From KD10,000 to KD } \\
50,000\end{array}$ & 71 & 54.6 & 2 & 15.4 & 38 & 52.8 & 22 & 64.7 & 9 & 71.0 \\
\hline & $\begin{array}{l}\text { From KD 50,000 to KD } \\
500,000\end{array}$ & 25 & 19.2 & 6 & 46.2 & 16 & 22.2 & 2 & 5.9 & 1 & 25.0 \\
\hline & $\begin{array}{l}\text { From KD 500,000 to KD } \\
\text { 5.0 Million }\end{array}$ & 4 & 3.1 & 2 & 15.4 & 0 & 0.0 & 2 & 5.9 & 0 & 4.0 \\
\hline & More than KD 5.0 Million & 5 & 3.8 & 3 & 23.1 & 2 & 2.8 & 0 & 0.0 & 0 & 5.0 \\
\hline \multirow{3}{*}{$\begin{array}{l}\text { Average } \\
\text { Holding Period }\end{array}$} & Less than 12 months & 54 & 41.9 & 5 & 41.7 & 28 & 38.9 & 14 & 41.2 & 7 & 63.6 \\
\hline & 13-24 months & 41 & 31.8 & 5 & 41.7 & 20 & 27.8 & 13 & 38.2 & 3 & 27.3 \\
\hline & More than 24 months & 34 & 26.4 & 2 & 16.7 & 24 & 33.3 & 7 & 20.6 & 1 & 9.1 \\
\hline \multirow{9}{*}{ Sector focus on } & Banking & 6 & 3.9 & 0 & 0.0 & 4 & 5.1 & 0 & 0.0 & 2 & 8.7 \\
\hline & Investment & 7 & 4.6 & 0 & 0.0 & 5 & 6.3 & 2 & 5.4 & 0 & 0.0 \\
\hline & Insurance & 1 & 0.7 & 1 & 7.7 & 0 & 0.0 & 0 & 0.0 & 0 & 0.0 \\
\hline & Real Estate & 4 & 2.6 & 0 & 0.0 & 3 & 3.8 & 0 & 0.0 & 1 & 4.3 \\
\hline & Industrial & 2 & 1.3 & 0 & 0.0 & 1 & 1.3 & 1 & 2.7 & 0 & 0.0 \\
\hline & Service & 3 & 2.0 & 0 & 0.0 & 2 & 2.5 & 0 & 0.0 & 1 & 4.3 \\
\hline & Food & 1 & 0.7 & 0 & 0.0 & 0 & 0.0 & 0 & 0.0 & 0 & 0.0 \\
\hline & Non-Kuwait & 0 & 0.0 & 0 & 0.0 & 0 & 0.0 & 1 & 2.7 & 0 & 0.0 \\
\hline & Multiple sectors* & 128 & 84.2 & 12 & 92.3 & 64 & 81.0 & 33 & 89.2 & 19 & 82.6 \\
\hline \multirow{6}{*}{$\begin{array}{l}\text { No. of } \\
\text { companies }\end{array}$} & $1-5$ companies & 70 & 46.7 & 3 & 23.1 & 41 & 52.6 & 18 & 50.0 & 8 & 34.8 \\
\hline & 6-10 companies & 45 & 30.0 & 1 & 7.7 & 24 & 30.8 & 9 & 25.0 & 11 & 47.8 \\
\hline & 11-15 companies & 16 & 10.7 & 4 & 30.8 & 8 & 10.3 & 3 & 8.3 & 1 & 4.3 \\
\hline & 16-20 companies & 12 & 8.0 & 2 & 15.4 & 5 & 6.4 & 2 & 5.6 & 3 & 13.0 \\
\hline & 21-30 companies & 2 & 1.3 & 1 & 7.7 & 0 & 0.0 & 1 & 2.8 & 0 & 0.0 \\
\hline & Over 30 companies & 5 & 3.3 & 2 & 15.4 & 0 & 0.0 & 3 & 8.3 & 0 & 0.0 \\
\hline
\end{tabular}

Note: The table shows the investment characteristics of the research participants. Specifically, it reports the average amount invested in, average holding period for a share, the area of investment focus and the number of shares invested in; these responses were available for 130,129, 152 and 150 participants for these questions respectively. An * denotes that participant focuses on more than sector.

\footnotetext{
${ }^{10}$ This finding confirms the discussions had with individual investors, as the questionnaires were distributed; most o stated they had been active traders rather than long-term investors until the Summer of 2008 when their KSE portfolios declined significantly causing them to get "locked into" the market; they did not want to realise any losses.

${ }_{11}$ Analysts reported t they do undertake some trades in the KSE in addition to their main job which is share analysis.
} 


\subsection{Share Valuation Methods Used}

Participants were asked how often they used each of the appraisal techniques (fundamental, technical and risk analysis) when evaluating their investments. Respondent views were sought on the usefulness of each of the three popular share valuation methods. A 5-point Likert scale was used for the first question where a score of ' 1 ' was given for "Never" used and a score of '5' was awarded for "Always" employed; in the second question, the LikertScale also ranged from 1 to 5 where 1 was "Not Useful" while 5 was "Extremely Useful". The responses are summarised in Table 4.

An analysis of Table 4 shows that fundamental analysis is the main valuation method used by the respondents in each group while technical and risk analyses are ranked second and third, respectively. For all the participants, fundamental analysis consistently achieved the highest mean score (3.77) and the lowest standard deviation (1.20); technical and risk analyses attracted lower means and higher standard deviation values. These findings are similar to the results in Arnold and Moizer (1984) and Arnold et al. (1984), as the current research suggests that fundamental analysis was employed by 91.4 per cent of the respondents.

One reason advanced to explain the importance attached to fundamental analysis is the influence of financial textbooks which do concentrate on this method of equity investment (Arnold, 2005; Wang et al., 2007). However, the use of technical and risk analyses seems higher in the current investigation than in the Arnold et al. findings for developed markets. Technical analysis was "sometimes" used by $74.7 \%$ of the sample, whereas risk analysis was employed by $54.2 \%$. The inefficiency of the KSE could explain the importance attached to technical analysis in Kuwait and risks factors like rumors, insider trading, and political risks might justify the use of risk analysis among respondents (Almujamed, 2011).

When the responses are studied individually, the null hypothesis that all four groups viewed fundamental, technical and risk analyses as being of equal importance was rejected since the $p$-values of 0.000 and 0.036 and 0.044 were less than the critical value of $0.05 .{ }^{12}$ In general, fund managers ranked all the techniques highest, while analysts gave approaches the second highest mean scores. Individual investors awarded them the third highest among scores, while stockbrokers had the smallest mean ratings. The only exception to this ranking was risk analysis where stockbrokers indicated that they used this approach more than their individual investor counterparts. Indeed, stockbrokers employed the appraisal techniques less frequently with the exception of the risk analysis (see Panel A of Table 4). This result is different from the findings in the substantive literature, which suggest that stockbrokers usually analyse shares according to fundamental and technical indicators (Tijjani, 2008). A possible explanation is that stockbrokers in Kuwait are banned from trading in the KSE (Almujamed, 2011). (see Footnote 8).

An analysis of Panel B of Table 4 shows that all three valuation methods appear to be useful since they have mean scores higher than 1.0 and also relatively low standard deviations. ${ }^{13}$ In general, perceptions of the usefulness of technical and risk analyses were not different across all four groups as tests of the null hypothesis that scores were equal could not be rejected due to $p$-values greater than 0.05 . This was not true for responses on the usefulness of fundamental analysis: a $p$-value of 0.000 indicated that the responses of fund managers (4.62), individual investors (3.78), analysts (4.27) and stockbrokers (3.67) were statistically different; these differences in views of the usefulness of fundamental analysis may have been due to the varied backgrounds about the respondents. Fund managers and analysts had more training in accounting and finance than did their individual investor and stockbroker counterparts.

A more detailed analysis of Panel B shows that technical analysis was ranked third (with the lowest mean) and seen as less useful than risk analysis by three of the four groups. Only the individual investors ranked technical

\footnotetext{
${ }^{12}$ A Kruskal-Wallis Test was used to test whether the equality of the means across different groups was significant and performed for all participants. Further, a Mann-Whitney test was performed to identify which pair of groups was different from each other by a statistically significant amount.

${ }^{13}$ A $t$ test was used to test whether the means differed from 1.00. A visual inspection of Panel B of Table 4 shows that all appraisal techniques were considered to be important and statistically did differ from 1.00.
} 
analysis second after fundamental analysis. One possible explanation for the perceived usefulness of technical analysis among individual investors might be that charts help this group select shares because the level of disclosure and transparency among companies in Kuwait remains low (Almujamed et al., 2010). Instead, risk analysis was useful for other participants possibly because of political and other uncertainties that are prominent in Kuwait (Almujamed, 2011).

\subsection{Use of Fundamental Analysis}

To further our understanding of the use of fundamental analysis, respondents were asked to comment on how often various measures (earnings, dividends, assets, ratios, or cash flows) were used when valuing the ordinary shares of Kuwaiti companies; ${ }^{14}$ these results are reported in Table 5. An analysis of this table reveals that all respondents ranked profitability ratios as the most important measure. Profitability had the highest mean score of 4.08 and the lowest standard deviation of 0.99 . Other measures, including growth ratios, estimated future dividends, and the P/E ratio, also had high mean scores of 3.87, 3.81, and 3.79, respectively. The DCF method was ranked last with a mean score of 3.27 and a standard deviation of 1.14. These findings are similar to those from other studies that have suggested that the P/E ratio is one of the most frequently used measures for valuing shares while DCF is employed less frequently (Arnold and Moizer, 1984; Al-Abdulqader et. al., 2007; Tijjani, 2008; Almujamed et al., 2010). Overall, the results for this current study suggest that respondents depend on accounting information rather than cash flows when valuing shares; investors, on the other hand, are interested in profits earned and dividends paid (Coleman and Eccles', 1997; Al-Abdulqader, 2007; Hassan and Power, 2009).

A disaggregated analysis of the results for the different participant groups shows that fund managers and analysts awarded these fundamental variables the highest mean scores while individual investors and stockbrokers gave them the lowest mean values. A statistical test of the null hypothesis, namely, that the means were equal across the different groups, was rejected for four of the fundamental factors: (i) growth ratios; (ii) the P/E ratio; (iii) the P/B ratio; and (iv) discounted future cash-flow analysis. When statistical analyses were performed for each pair of groups, the $p$-values for these factors were less than the critical value of 0.05 . For instance, a $p$-value of 0.000 indicated that the P/E ratio was awarded different mean scores by fund managers (4.69), individual investors (3.45), analysts (4.22) and stockbrokers (3.57). Further analysis shows that analysts and fund managers shared the same views regarding the importance of fundamental measures since their rankings were similar. For example, such measures as the $\mathrm{P} / \mathrm{E}$ ratio, profitability ratios, growth ratios, and the $\mathrm{P} / \mathrm{B}$ ratio, were usually ranked in the top positions by both analysts and fund managers. In contrast, such factors as DCF analysis, turnover ratios, and net asset values were not considered to the same extent. Overall, differences in the perception of the use of fundamental measures between analysts, fund managers, individual investors, and stockbrokers may be due to the different analyses that each performs when valuing ordinary shares. Certainly, the stockbrokers did focus on a range of financial statement ratios, while individual investors concentrated on profitability and dividends.

\subsection{Use of Technical Analysis}

Questions were also asked about the use of technical analysis by research participants ${ }^{15}$. The findings are reported in Table 6 where a number of points emerged. First, the respondents indicated all chart techniques were either 'usually' or 'always' used, including "the highest and the lowest price", "trading volume", " support and the resistance levels", "any trend in share price", "volatility of the share price" and "average price of the share in the past." Filter rules were an exception to this generalization and not as extensively employed since they had a mean score of only 2.50 and a standard deviation of 1.24. This finding is similar to the results documented in the substantive literature on emerging markets for China (Xu, 2010) and Kuwait (Almujamed et al., 2010). In particular, Almujamed et al. (2010) found that none of the 16 Kuwaiti interviewees from their study used filter rule strategies although the profitability of these rules had already been highlighted in previous studies (Al-Shamali, 1989).

\footnotetext{
${ }^{14}$ A 5-point Likert-scale was used where a score of '1' was given for "Never" and '5' for "Always".

${ }^{15}$ A 5-point Likert Scale where a score of '1' was given to "Never" and a '5' given for "Always" explored the perceptions of the respondents and the extent to which they used various technical factors when appraising share prices.
}

C) 2012 The Clute Institute http://www.cluteinstitute.com/ 
Table 4: Participants' Views on Share Valuation Methods

\begin{tabular}{|c|c|c|c|c|c|c|c|c|c|c|c|c|c|c|c|c|}
\hline \multirow[t]{2}{*}{ Statements } & \multicolumn{3}{|c|}{ All Participants } & \multicolumn{3}{|c|}{ FM } & \multicolumn{3}{|c|}{ IV } & \multicolumn{3}{|c|}{ AN } & \multicolumn{3}{|c|}{ SB } & \multirow{2}{*}{$\begin{array}{c}\text { P- } \\
\text { value } \\
(\mathrm{K}-\mathrm{W}) \\
\end{array}$} \\
\hline & Mean & SD & Rank & Mean & SD & Rank & Mean & SD & Rank & Mean & SD & Rank & Mean & SD & Rank & \\
\hline \multicolumn{17}{|c|}{$\begin{array}{l}\text { (A) How often do use this share } \\
\text { valuation method? }\end{array}$} \\
\hline Fundamental analysis & 3.77 & 1.20 & 1 & 4.69 & 0.63 & 1 & 3.58 & 1.19 & 1 & 4.13 & 1.14 & 1 & 3.29 & 1.20 & 1 & $0.000 *$ \\
\hline Technical analysis & 3.29 & 1.31 & 2 & 3.92 & 1.19 & 2 & 3.09 & 1.34 & 2 & 3.66 & 1.19 & 2 & 3.04 & 1.27 & 3 & $0.036^{*}$ \\
\hline Risk Analysis & 3.04 & 1.39 & 3 & 3.85 & 1.07 & 3 & 2.78 & 1.39 & 3 & 3.24 & 1.36 & 3 & 3.13 & 1.42 & 2 & $0.044 *$ \\
\hline \multicolumn{17}{|c|}{$\begin{array}{l}\text { (B) How useful are these appraisal } \\
\text { techniques? }\end{array}$} \\
\hline Fundamental analysis & $3.97 * *$ & 0.88 & 1 & $4.62 * *$ & 0.65 & 1 & $3.78 * *$ & 0.86 & 1 & $4.27 * *$ & 0.77 & 1 & $3.67 * *$ & 0.91 & 1 & $0.000 *$ \\
\hline Technical analysis & $3.65 * *$ & 0.88 & 3 & $3.69 * *$ & 1.03 & 3 & $3.62 * *$ & 0.82 & 2 & $3.77 * *$ & 1.03 & 3 & $3.50 * *$ & 0.69 & 3 & 0.721 \\
\hline Risk Analysis & $3.74 * *$ & 0.93 & 2 & $4.27 * *$ & 0.65 & 2 & $3.59 * *$ & 0.89 & 3 & $3.91 * *$ & 0.93 & 2 & $3.60 * *$ & 1.10 & 2 & 0.088 \\
\hline
\end{tabular}

Note: This table reports the frequency with which fundamental, technical and risk analysis are used by all participants and the usefulness of each appraisal technique. A five-point Likert-Scale was used ranging from $1=$ 'Never' to $5=$ 'Always' for question (A) and from $1=$ 'Not Useful' to $5=$ 'Extremely Useful' for question (B). The mean (Mean) score and the standard deviation (SD) of each factor is shown together with a ranking based the Means. This information is presented: (i) for participants and individual groups. Finally, the $p$ - value (Kruskal-Wallis) for a test of equality of means across different groups is provided. For Panel (B) an ** denotes that the mean is significantly different from 1.00 . An * and ** significance at the 5.0 per cent level.

Table 5: Analysis of the Factors Considered when Using Fundamental Analysis

\begin{tabular}{|c|c|c|c|c|c|c|c|c|c|c|c|c|c|c|c|c|}
\hline \multirow[t]{2}{*}{ Statements } & \multicolumn{3}{|c|}{ Participants } & \multicolumn{3}{|c|}{ FM } & \multicolumn{3}{|c|}{ IV } & \multicolumn{3}{|c|}{$\mathbf{A N}$} & \multicolumn{3}{|c|}{ SB } & \multirow{2}{*}{$\begin{array}{c}\text { P-value } \\
\text { (K-W) }\end{array}$} \\
\hline & Mean & SD & Rank & Mean & SD & Rank & Mean & SD & Rank & Mean & SD & Rank & Mean & SD & Rank & \\
\hline Profitability ratios & 4.08 & 0.99 & 1 & 4.54 & 0.66 & 2 & 4.05 & 0.98 & 1 & 4.14 & 1.10 & 2 & 3.80 & 0.89 & 1 & 0.078 \\
\hline Growth ratios & 3.87 & 1.15 & 2 & 4.46 & 0.78 & 3 & 3.75 & 1.11 & 4 & 4.00 & 1.31 & 4 & 3.62 & 1.07 & 4 & $0.042 *$ \\
\hline Estimated future dividends & 3.81 & 1.01 & 3 & 4.23 & 0.73 & 6 & 3.80 & 0.96 & 3 & 3.86 & 1.13 & 7 & 3.52 & 1.08 & 6 & 0.251 \\
\hline $\mathrm{P} / \mathrm{E}$ ratio & 3.79 & 1.17 & 4 & 4.69 & 0.48 & 1 & 3.45 & 1.24 & 7 & 4.22 & 1.06 & 1 & 3.57 & 0.93 & 5 & $0.000^{*}$ \\
\hline Debt ratios & 3.76 & 1.24 & 5 & 4.31 & 0.85 & 5 & 3.55 & 1.26 & 5 & 3.95 & 1.31 & 6 & 3.71 & 1.15 & 2 & 0.109 \\
\hline Forecast of earnings for the coming year & 3.75 & 1.00 & 6 & 4.15 & 0.99 & 7 & 3.83 & 0.93 & 2 & 3.70 & 1.08 & 8 & 3.35 & 1.04 & 9 & 0.122 \\
\hline Liquidity ratios & 3.69 & 1.25 & 7 & 4.08 & 0.95 & 8 & 3.45 & 1.27 & 6 & 3.97 & 1.28 & 5 & 3.67 & 1.24 & 3 & 0.097 \\
\hline $\mathrm{P} / \mathrm{B}$ ratio & 3.56 & 1.19 & 8 & 4.31 & 0.63 & 4 & 3.24 & 1.15 & 9 & 4.05 & 1.22 & 3 & 3.24 & 1.04 & 10 & $0.000^{*}$ \\
\hline Net asset value & 3.50 & 1.23 & 9 & 3.77 & 1.17 & 11 & 3.38 & 1.26 & 8 & 3.64 & 1.31 & 9 & 3.43 & 1.08 & 7 & 0.595 \\
\hline Turnover ratios & 3.39 & 1.23 & 10 & 4.08 & 1.04 & 9 & 3.19 & 1.26 & 10 & 3.50 & 1.28 & 10 & 3.38 & 1.07 & 8 & 0.121 \\
\hline Discounted future cash-flows & 3.27 & 1.14 & 11 & 3.85 & 0.99 & 10 & 3.17 & 1.15 & 11 & 3.49 & 1.22 & 11 & 2.86 & 0.91 & 11 & $0.046^{*}$ \\
\hline
\end{tabular}

Note: This table reports the Likert-Scale for questions about the factors used by 137 of the research participants when valuing shares using fundamental analysis. A five-point Likert-Scale was used ranging from $1=$ 'Never' to $5=$ 'Always'. Finally, the $p$ - value (Kruskal-Wallis) for a test of equality of means across different groups is provided. An * significance at the 5.0 per cent level. 
Second, the null hypothesis that all four groups considered "support and resistance level", "volatility of share price" and " average price of the share in the past" to the same extent when valuing shares was rejected since their $p$-values of $0.012,0.003$ and 0.016 , respectively, were less than the critical value of 0.05 . Third, when the responses for the different groups were investigated separately, fund managers 'always' or 'usually' consider the "volatility of share price", " average price of the share in the past" and "support and resistance levels" . These variables achieved mean scores higher than 4.37; analysts were not fundamentally different from fund managers in terms of the approaches they adopted. By contrast, individual investors and stockbrokers used these factors less frequently.

\subsection{Use of Risk Analysis}

Respondents were also asked about the factors they considered when undertaking risk analysis (Table 7). Overall, it appears that all risk factors were considered by those answering the questionnaires; the means ranged from a high of 3.93 for "risk attributes unique to a particular firm" to a low of 2.50 for "fluctuation in exchange rates"16; obviously, many respondents only invest in local firms which do not export or import raw materials, such that currency risk was considered less of an issue than the other listed variables. Each group of participants also tended to rank risk factors differently. For example, analysts and fund managers 'always' or 'usually' looked at "risk attributes unique to a particular firm" and "liquidity risk" when buying and selling a share; both of these risk factors had mean scores higher than 4.05 for these two groups. Fund managers and analysts possibly held undiversified portfolios and thus a concern regarding unique risk and thin trading issues for their Kuwaiti equity investments.

Other risk factors, such as "conflict between the government and the Kuwaiti parliament" and "political risk in the Gulf and Middle Eastern region" were also rated highly with mean scores of 3.74 and relatively low standard deviations of 0.99 and 1.09, respectively. Interesting enough, individual investors ranked both of these factors as the one risk they considered most when evaluating their investments. Almujamed (2011) argued that these risks caused the Kuwaiti market to be volatile in the short-run, which tended also to be the investment horizon employed by individual investors. In contrast, stockbrokers focused most on the risk of a crash. This risk factor had a mean score of 3.95 and was possibly highlighted because stockbrokers may have been worried about the impact of this specific event on commission fees after the appetite of investors for equity investment declined following the earlier large market fall in 2008.

The null hypotheses that all four groups viewed "liquidity risk associated with shares when deciding to make investment decisions" and seeing the "risk of fluctuations in interest rates" as being of equal importance was rejected since their $p$-values were 0.014 and 0.015 , respectively. For instance, a visual inspection of Table 7 shows that risk of fluctuations in interest rates achieved mean scores that were much lower for individual investors (2.97) and stockbrokers (3.30) than for the analysts (3.53) and fund managers (4.08).

\subsection{Sources of Information Used}

Respondents were asked to comment on how often they considered 10 different sources of information when deciding to invest in the KSE (Table 8) ${ }^{17}$. A 5-point Likert-Scale was employed where the values ranged from $1=$ 'Never' to $5=$ 'Always'.

An analysis of Table 8 shows that respondents perceived corporate annual reports and company quarterly reports as the most frequently used sources of information; both were given the highest mean scores of 3.62 and 3.53 , respectively. Newspapers, the KSE's website, advice from friends, and charts were also consulted by the participants, but less frequently; they had mean scores that ranged from 3.27 to 3.44. By contrast, "Discussion with company staff" was the least used source of information. This finding is different from the results documented in the

\footnotetext{
${ }^{16}$ Not surprisingly, this finding was supported by the exchange rate for the Kuwaiti Dinar being relatively stable (Almujamed, 2011).

17 The researchers built the information lists from the substantive literature and discussions with those who piloted the questionnaire. In addition, free space was left for the participants to list other sources not listed on the questionnaires. However, none of the respondents listed any new sources in this regard.
}

(C) 2012 The Clute Institute http://www.cluteinstitute.com/ 
recent literature where analysts in both the U.K. and the U.S. rated their discussions with corporate management as growing in importance (Pike et al., 1993; Barker, 1999, Clatworthy, 2005). Management of Kuwaiti quoted companies may be more hesitant about discussing their firm's current and future performance especially with individual investors, analysts, and stockbrokers, as the culture of secrecy is more pronounced in Gulf countries like Kuwait (Almujamed, 2011).

Not all respondent groups rated the different sources equally; the null hypothesis that all four groups equally consulted the annual report, the quarterly report, the KSE website, charts and discussions with company staff was rejected since their $p$-values were less than the critical value of 0.05 . For example, fund mangers ranked discussion with company personnel sixth while the other groups of participants ranked it last. Fund managers may also have had more access to company staff than the other groups of participants. Interestingly, individual investors responded differently when answering this question; they usually depended on advice from a friend when evaluating a stock; this source of information received a high mean score (3.34) and low standard deviation (0.99) relative to the other sources listed. The microstructure of the KSE and the context of individual investors in Kuwait could explain this result since informal communication is prevalent in the main trading hall.

Participants were also asked to comment on the importance that they attached to different sections of a corporate annual report. A 5-point Likert scale was used to grade these questions about the importance of items in a company's annual report, ranging from '1' for "Unimportant" to '5' for "Very Important". A visual inspection of Table 9 shows that all parts of a company's annual report are seen as important except for the "Directors' report" and the "Chairmen's statement". Both were perceived by the participants as the least important sections of a firm's annual report with mean scores of 3.13 and 3.03, respectively. The most important part of the Annual Report for all groups was the Balance Sheet, followed by the Profit and Loss Account and the Cash Flow Statement.

When the views of the different types of respondents were examined separately, the null hypothesis that all four groups viewed the "Balance Sheet", "Profit and Loss Account", "Cash Flow Statement" and "Notes to Accounts" as being equally important was rejected since their $p$-values of $0.005,0.034,0.004$ and 0.011 , respectively, were less than the critical value of 0.05 . Analysts, fund managers, and stockbrokers perceived the Balance Sheet, Profit and Loss Account and Cash Flow Statement as very important and awarded these items relatively higher mean scores than did their individual investor counterparts. However, a full analysis of Table 9 shows that while there may have been differences in the mean scores across the four sub-groups, there was no major variation in the actual ranking of the different sections of a company's Annual Report.

To build a complete picture of the sources of information used in Kuwait with respect to equity investment analysis, respondents were asked to comment on the importance of non-financial information. Again, a 5-point Likert Scale was used, ranging from '1' for "Unimportant" to ' 5 ' for "Very Important". The results are displayed in Table 10. The overall purpose of the questionnaire was to ascertain respondent views on a list of items used when evaluating equity investment decisions. A number of conclusions emerge from a visual inspection of Table 10. For example, the respondents gave a high ranking to "New contracts won by the company" (mean $=4.19)$, "Takeover decisions" (mean $=4.07)$, "Launch of a new project" (mean $=3.90)$, and a "Change in company plans" (mean= 3.90). These means also were associated with relatively low standard deviations, suggesting that the respondents were in agreement about the importance of these news items. "A change in the firm's product prices" or "A change in a firm's control system" was perceived by the respondents as being the least important news items with mean scores of 3.22 and 3.21, respectively. Overall, the findings are relatively similar for all the groups. However, the null hypothesis that all four groups viewed news of a company's expansion as being of equal importance was rejected since the $p$-value was less than the critical value of 0.05 . An analysis was also performed to identify which participant group was different. It showed that fund managers perceived news of a company's expansion plans as more important $($ mean $=4.62)$ relative to the views of individual investors $($ mean $=4.01)$ and stockbrokers $($ mean $=$ 3.79). One explanation for this finding could be that fund managers tend to undertake longer-term investments and take into consideration expected returns from a company's expansion plans compared to individual investors and stockbrokers who mainly focus on stock speculation (see Table 2). 


\begin{tabular}{|c|c|c|c|c|c|c|c|c|c|c|c|c|c|c|c|c|}
\hline \multirow[t]{2}{*}{ Statements } & \multicolumn{3}{|c|}{ Participants } & \multicolumn{3}{|c|}{ FM } & \multicolumn{3}{|c|}{ IV } & \multicolumn{3}{|c|}{$\mathbf{A N}$} & \multicolumn{3}{|c|}{ SB } & \multirow{2}{*}{$\begin{array}{c}\text { P-value } \\
\text { (K-W) }\end{array}$} \\
\hline & Mean & SD & Rank & Mean & SD & Rank & Mean & SD & Rank & Mean & SD & Rank & Mean & SD & Rank & \\
\hline Highest and the lowest price & 4.26 & 0.83 & 1 & 4.54 & 0.78 & 2 & 4.14 & 0.88 & 1 & 4.37 & 0.81 & 2 & 4.26 & 0.65 & 1 & 0.320 \\
\hline Trading volume & 4.04 & 0.87 & 2 & 4.00 & 0.82 & 6 & 4.00 & 0.94 & 2 & 4.23 & 0.84 & 3 & 3.85 & 0.67 & 4 & 0.432 \\
\hline Support and the resistance level & 3.99 & 1.11 & 3 & 4.38 & 1.04 & 4 & 3.69 & 1.21 & 3 & 4.38 & 0.92 & 1 & 4.05 & 0.83 & 2 & $0.012 *$ \\
\hline Any trend in share price in the market & 3.88 & 1.14 & 4 & 4.23 & 1.09 & 5 & 3.67 & 1.22 & 4 & 4.17 & 1.01 & 4 & 3.80 & 1.01 & 5 & 0.112 \\
\hline Volatility of the share price & 3.86 & 0.95 & 5 & 4.62 & 0.51 & 1 & 3.62 & 0.96 & 5 & 4.00 & 1.06 & 5 & 3.90 & 0.64 & 3 & $0.003 *$ \\
\hline The average price of the share in the past & 3.77 & 1.00 & 6 & 4.38 & 0.65 & 3 & 3.55 & 1.03 & 6 & 4.00 & 1.06 & 6 & 3.65 & 0.75 & 6 & $0.016^{*}$ \\
\hline Filter Rules & 2.50 & 1.24 & 7 & 2.62 & 1.33 & 7 & 2.33 & 1.31 & 7 & 2.63 & 1.24 & 7 & 2.70 & 0.98 & 7 & 0.549 \\
\hline
\end{tabular}

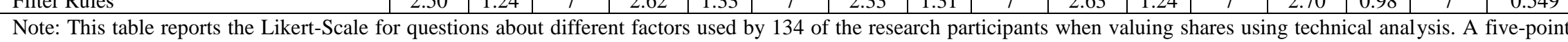
Likert-Scale was used ranging from $1=$ 'Never' to 5 = 'Always'. Finally, the $p$ - value (Kruskal-Wallis) for a test of equality of means across different groups is provided. An * significance at the 5.0 per cent level.

Table 7: Analysis of the Factors Considered when Using Risk Analysis

\begin{tabular}{|c|c|c|c|c|c|c|c|c|c|c|c|c|c|c|c|c|}
\hline \multirow[t]{2}{*}{ Statements } & \multicolumn{3}{|c|}{ Participants } & \multicolumn{3}{|c|}{ FM } & \multicolumn{3}{|c|}{ IV } & \multicolumn{3}{|c|}{$\mathbf{A N}$} & \multicolumn{3}{|c|}{ SB } & \multirow{2}{*}{$\begin{array}{l}\text { P-value } \\
\text { (K-W) }\end{array}$} \\
\hline & Mean & SD & Rank & Mean & SD & Rank & Mean & SD & Rank & Mean & SD & Rank & Mean & SD & Rank & \\
\hline $\begin{array}{l}\text { Risk attributes that are unique to a } \\
\text { particular firm }\end{array}$ & 3.93 & 1.04 & 1 & 4.50 & 0.67 & 1 & 3.83 & 0.99 & 3 & 4.06 & 1.05 & 2 & 3.63 & 1.26 & 5 & 0.100 \\
\hline $\begin{array}{l}\text { Liquidity risk when buying and selling a } \\
\text { share }\end{array}$ & 3.90 & 0.99 & 2 & 4.42 & 0.51 & 2 & 3.72 & 1.01 & 5 & 4.22 & 1.01 & 1 & 3.60 & 0.94 & 6 & $0.014 *$ \\
\hline $\begin{array}{l}\text { Conflict between the government and the } \\
\text { Kuwaiti parliament }\end{array}$ & 3.74 & 0.99 & 3 & 3.75 & 0.75 & 7 & 3.88 & 0.87 & 1 & 3.38 & 1.24 & 8 & 3.90 & 0.97 & 2 & 0.107 \\
\hline $\begin{array}{l}\text { Political risk in the Gulf and Middle } \\
\text { Eastern region }\end{array}$ & 3.74 & 1.09 & 4 & 3.75 & 0.87 & 8 & 3.88 & 1.05 & 2 & 3.47 & 1.16 & 7 & 3.75 & 1.16 & 3 & 0.395 \\
\hline Fraud within the firm & 3.74 & 1.18 & 5 & 4.17 & 1.11 & 3 & 3.79 & 1.14 & 4 & 3.75 & 1.05 & 3 & 3.30 & 1.45 & 8 & 0.214 \\
\hline $\begin{array}{l}\text { Risk of a crash in the Kuwaiti stock } \\
\text { market }\end{array}$ & 3.64 & 1.27 & 6 & 4.00 & 1.21 & 6 & 3.64 & 1.27 & 6 & 3.31 & 1.26 & 9 & 3.95 & 1.32 & 1 & 0.236 \\
\hline $\begin{array}{l}\text { The past volatility of the share's price } \\
\text { relative to an index }\end{array}$ & 3.59 & 1.02 & 7 & 4.08 & 0.79 & 5 & 3.56 & 1.07 & 8 & 3.66 & 0.90 & 4 & 3.30 & 1.13 & 9 & 0.206 \\
\hline Risk of an overseas crisis & 3.58 & 1.04 & 8 & 3.58 & 0.79 & 9 & 3.60 & 1.04 & 7 & 3.50 & 1.08 & 6 & 3.65 & 1.14 & 4 & 0.960 \\
\hline Fluctuations in interest rates & 3.27 & 1.24 & 9 & 4.08 & 0.90 & 4 & 2.97 & 1.22 & 9 & 3.53 & 1.24 & 5 & 3.30 & 1.22 & 7 & $0.015^{*}$ \\
\hline Fluctuations in exchange rates & 2.50 & 1.27 & 10 & 3.00 & 1.28 & 10 & 2.30 & 1.30 & 10 & 2.84 & 1.27 & 10 & 2.30 & 1.03 & 10 & 0.096 \\
\hline
\end{tabular}
Scale was used ranging from $1=$ 'Never' to $5=$ 'Always'. Finally, the $p$-value (Kruskal-Wallis) for a test of equality of means across different groups is provided. An * significance at the 5.0 per cent level. 
Table 8: Source of Information Used when Evaluating A Firm's Share

\begin{tabular}{|c|c|c|c|c|c|c|c|c|c|c|c|c|c|c|c|c|}
\hline \multirow[t]{2}{*}{ Statements } & \multicolumn{3}{|c|}{ All Participants } & \multicolumn{3}{|c|}{ FM } & \multicolumn{3}{|c|}{ IV } & \multicolumn{3}{|c|}{$\mathbf{A N}$} & \multicolumn{3}{|c|}{ SB } & \multirow{2}{*}{$\begin{array}{c}\text { P-value } \\
\text { (K-W) }\end{array}$} \\
\hline & Mean & SD & Rank & Mean & SD & Rank & Mean & SD & Rank & Mean & SD & Rank & Mean & SD & Rank & \\
\hline Company annual report & 3.62 & 1.26 & 1 & 4.85 & 0.38 & 1 & 3.34 & 1.25 & 2 & 3.87 & 1.14 & 1 & 3.50 & 1.22 & 1 & $0.000^{*}$ \\
\hline Company quarterly reports & 3.53 & 1.26 & 2 & 4.85 & 0.38 & 2 & 3.15 & 1.25 & 5 & 3.84 & 1.26 & 2 & 3.50 & 1.18 & 2 & $0.000^{*}$ \\
\hline Newspapers & 3.44 & 1.06 & 3 & 3.85 & 1.07 & 5 & 3.29 & 1.03 & 4 & 3.63 & 1.00 & 5 & 3.42 & 1.21 & 3 & 0.194 \\
\hline Kuwait Stock Exchange Website & 3.35 & 1.34 & 4 & 4.08 & 1.04 & 3 & 3.34 & 1.29 & 3 & 3.82 & 1.31 & 3 & 2.25 & 1.03 & 9 & $0.000^{*}$ \\
\hline Friend's advice & 3.28 & 1.02 & 5 & 4.00 & 1.08 & 4 & 3.44 & 0.99 & 1 & 3.11 & 1.11 & 6 & 3.21 & 1.02 & 4 & 0.261 \\
\hline Charts & 3.27 & 1.36 & 6 & 2.69 & 1.25 & 10 & 2.96 & 1.31 & 6 & 3.81 & 1.33 & 4 & 3.04 & 1.36 & 5 & $0.002^{*}$ \\
\hline Insider information & 2.68 & 1.26 & 7 & 3.31 & 1.11 & 7 & 2.51 & 1.26 & 8 & 2.84 & 1.35 & 7 & 2.63 & 1.13 & 7 & 0.146 \\
\hline Stockbrokers & 2.54 & 1.16 & 8 & 2.77 & 1.01 & 9 & 2.42 & 1.12 & 9 & 2.42 & 1.24 & 8 & 3.00 & 1.14 & 6 & 0.132 \\
\hline Tips and rumours & 2.53 & 1.11 & 9 & 3.00 & 0.91 & 8 & 2.64 & 1.08 & 7 & 2.24 & 1.08 & 9 & 2.54 & 1.25 & 8 & 0.298 \\
\hline Discussions with company staff & 2.05 & 1.18 & 10 & 3.31 & 1.38 & 6 & 1.72 & 1.02 & 10 & 2.24 & 1.02 & 10 & 2.13 & 1.25 & 10 & $0.000^{*}$ \\
\hline
\end{tabular}

\begin{tabular}{|l|l|l|l|l|l|l|l|l|l|l|l} 
Discussions with company staff & 2.05 & 1.18 & 10 & 3.31 & 1.38 & 6 & 1.72 & 1.02 & 10 & 2.24 & 1.02 \\
\hline
\end{tabular} from $1=$ 'Never' to $5=$ 'Always'. Finally, the $p$ - value (Kruskal-Wallis) for a test of equality of means across different groups is provided. An * significance at the 5.0 per cent level.

Table 9: The Important of Sections in Company's Annual Reports

\begin{tabular}{|c|c|c|c|c|c|c|c|c|c|c|c|c|c|c|c|c|}
\hline \multirow[t]{2}{*}{ Statements } & \multicolumn{3}{|c|}{ All Participants } & \multicolumn{3}{|c|}{ FM } & \multicolumn{3}{|c|}{ IV } & \multicolumn{3}{|c|}{$\mathbf{A N}$} & \multicolumn{3}{|c|}{ SB } & \multirow{2}{*}{$\begin{array}{l}\text { P-value } \\
\text { (K-W) }\end{array}$} \\
\hline & Mean & SD & Rank & Mean & SD & Rank & Mean & SD & Rank & Mean & SD & Rank & Mean & SD & Rank & \\
\hline Balance Sheet & 4.40 & 0.81 & 1 & 4.92 & 0.28 & 1 & 4.13 & 0.92 & 1 & 4.58 & 0.66 & 2 & 4.45 & 0.69 & 1 & $0.005^{*}$ \\
\hline Profit and Loss Account & 4.38 & 0.97 & 2 & 4.77 & 0.44 & 2 & 4.02 & 1.05 & 2 & 4.73 & 0.72 & 1 & 4.36 & 1.21 & 3 & $0.034 *$ \\
\hline Cash Flow Statement & 4.29 & 0.99 & 3 & 4.77 & 0.44 & 3 & 4.00 & 1.10 & 3 & 4.48 & 0.91 & 3 & 4.40 & 0.84 & 2 & $0.004^{*}$ \\
\hline Notes to Accounts & 4.09 & 1.08 & 4 & 4.69 & 0.63 & 4 & 3.80 & 1.02 & 4 & 4.36 & 1.03 & 4 & 3.73 & 1.42 & 4 & $0.011^{*}$ \\
\hline Auditor's report & 3.64 & 1.26 & 5 & 4.38 & 0.87 & 5 & 3.45 & 1.06 & 5 & 3.64 & 1.43 & 5 & 3.60 & 1.71 & 5 & 0.128 \\
\hline Directors' report & 3.13 & 1.24 & 6 & 3.08 & 1.26 & 6 & 3.04 & 1.20 & 6 & 3.27 & 1.26 & 6 & 3.09 & 1.45 & 7 & 0.875 \\
\hline Chairman's statement & 3.03 & 1.33 & 7 & 2.92 & 1.26 & 7 & 2.96 & 1.35 & 7 & 3.15 & 1.28 & 7 & 3.09 & 1.58 & 6 & 0.916 \\
\hline
\end{tabular}

Note: This table reports the Likert-Scale for questions about the important of items in a company's annual reports from the perspective of the research participants. A five-point Likert-Scale was used ranging from $1=$ 'Unimportant' to $5=$ 'Very Important'. Finally, the $p$ - value (Kruskal-Wallis) for a test of equality of means across different groups is provided. An * significance at the 5.0 per cent level. 
Table 10: The Importance of Non-Financial Information

\begin{tabular}{|c|c|c|c|c|c|c|c|c|c|c|c|c|c|c|c|c|}
\hline \multirow[t]{2}{*}{ Statements } & \multicolumn{3}{|c|}{ All Participants } & \multicolumn{3}{|c|}{ FM } & \multicolumn{3}{|c|}{ IV } & \multicolumn{3}{|c|}{$\mathbf{A N}$} & \multicolumn{3}{|c|}{ SB } & \multirow[t]{2}{*}{$\begin{array}{c}\text { P-value } \\
\text { (K-W) }\end{array}$} \\
\hline & Mean & SD & Rank & Mean & SD & Rank & Mean & SD & Rank & Mean & SD & Rank & Mean & SD & Rank & \\
\hline New contracts won by the company & 4.19 & 0.76 & 1 & 4.38 & 0.65 & 3 & 4.12 & 0.81 & 1 & 4.29 & 0.73 & 1 & 4.17 & 0.70 & 1 & 0.519 \\
\hline Takeover decision & 4.07 & 0.87 & 2 & 4.46 & 0.66 & 2 & 3.94 & 0.93 & 3 & 4.24 & 0.85 & 2 & 4.04 & 0.69 & 2 & 0.113 \\
\hline Company expansion & 4.07 & 0.88 & 3 & 4.62 & 0.51 & 1 & 4.01 & 0.90 & 2 & 4.16 & 0.89 & 3 & 3.79 & 0.83 & 3 & $0.042 *$ \\
\hline Launch of a new project & 3.90 & 0.87 & 4 & 4.00 & 0.82 & 5 & 3.87 & 0.93 & 4 & 3.97 & 0.82 & 4 & 3.79 & 0.83 & 4 & 0.832 \\
\hline A change in company plans & 3.83 & 0.89 & 5 & 4.00 & 0.71 & 4 & 3.83 & 0.93 & 5 & 3.92 & 0.94 & 5 & 3.58 & 0.78 & 5 & 0.445 \\
\hline A change in the firm's structure & 3.66 & 1.05 & 6 & 3.77 & 1.30 & 7 & 3.63 & 1.05 & 6 & 3.76 & 1.08 & 6 & 3.54 & 0.93 & 6 & 0.833 \\
\hline $\begin{array}{l}\text { A change in chairman or board member/ } \\
\text { large shareholder }\end{array}$ & 3.46 & 1.16 & 7 & 3.62 & 1.19 & 8 & 3.47 & 1.24 & 7 & 3.57 & 1.04 & 8 & 3.17 & 1.05 & 7 & 0.558 \\
\hline A change in products, services or quality & 3.45 & 1.07 & 8 & 3.92 & 0.86 & 6 & 3.40 & 1.08 & 8 & 3.58 & 0.98 & 7 & 3.17 & 0.87 & 8 & 0.150 \\
\hline A change in the firm's product prices & 3.22 & 1.10 & 9 & 3.54 & 1.20 & 9 & 3.15 & 1.07 & 10 & 3.39 & 1.03 & 9 & 2.96 & 1.23 & 10 & 0.299 \\
\hline A change in the firm's control system & 3.21 & 1.08 & 10 & 3.08 & 1.12 & 10 & 3.18 & 1.10 & 9 & 3.34 & 1.17 & 10 & 3.13 & 1.22 & 9 & 0.836 \\
\hline
\end{tabular}

Note: This table reports the Likert-Scale for questions about the important of non-financial information from the prospect of research participants. A five-point Likert-Scale was used ranging from $1=$ 'Unimportant' to $5=$ 'Very Important'. Finally, the $p$-value (Kruskal-Wallis) for a test of equality of means across different groups is provided. An * significance at the 5.0 per cent level. 


\section{CONCLUSION AND DISCUSSION}

This study offers specific insights into the equity investment practices of investors where only limited research has previously been undertaken. It presents the findings of a questionnaire survey about valuation methods and information sources specifically used by Kuwaiti investors, analysts, and stockbrokers when making their security appraisal decisions. Kuwaiti respondents are similar to their counterparts in the developed and other emerging stock markets in the sense that they use fundamental analysis as their main approach for analysing ordinary shares. Technical and risk analyses were also important, but ranked second and third, respectively.

In Kuwait, information about profitability ratios, growth ratios, estimated future dividends and P/E ratio were the most important factors considered when valuing ordinary shares. By contrast, the DCF approach was considered least important. Investors based their decisions mainly on corporate reports and focused on the Balance Sheet and Profit and Loss Account. By contrast, discussions with company management were not considered an important influence on investment decisions; investors in fact indicated that managment were not willing to discuss their firms' current and future performances with investors. Such a result is different from the findings reported in the substantive literature for developed markets where discussion with corporate management is viewed as important (Pike et al., 1993; Barker, 1999, Clatworthy, 2005). Other sources like newspapers, the KSE website, advice from friends, and technical charts were also recognised as important by investors in Kuwait. In addition, certain news items, such as "new contracts won by the company", "takeover decisions", and "the launch of new projects" were seen as important by all the respondents.

Investors commonly studied technical factors, such as highest and the lowest price, trading volume, support and resistance level, trends in share prices, volatility of share returns and the average past price of a share, before making investment decisions. The respondents also considered risk; such a finding is hardly surprising since the KSE does not have an independent regulator, and rules that prohibit insider trading do not exist. In addition, political risk in Kuwait and the rest of the Gulf region is probably higher than in developed countries.

A number of recommendations emerge from this analysis. For example, regulator interested in promoting the efficiency of the KSE might wish to strengthen insider trading rules and lesser the impact of rumors on the equity decision of investors. The regulators might want to co-ordinate the disclosure of price sensitive information to investors in order to reduce any reliance on rumors. Another recommendation from this paper is that investors may need to be educated by the KSE authorities about the risks that they might focus on. For instance, if diversified portfolios are held, then interest in form-specific risk attributes may not be necessary. In addition, KSE authority may need to ensure that annual report of listed companies is published in timely fashion since a lot of investors seems to rely on its contents when undertaken their fundamental analysis.

Future research might build on the findings in the current study by investigating how investors incorporate different aspects of risk, technical indicators and company fundamentals into their security evaluations overall. Further research effort in this area might also examine whether some of the variables addressed in this study also statistically associate with share prices. In addition, ethnographic studies might investigate how informal communication channels and rumors spread throughout the Kuwaiti market through spending time in the trading hall of the KSE. All of these possible avenues for future research could add significantly to the findings of the current study.

\section{ACKNOWLEDGEMENTS}

The authors want to thank a number of people who helped make this research possible: Abduallah Almujamed, Ahmad Alkoufaidi, Adnan Al-Sharah, Ahmed Al-Munis and Yaqoup Al-Bash.

\section{AUTHOR INFORMATION}

Hesham I. Almujamed, PhD: Obtained his doctorate from the University of Dundee (UK). He is currently assistant professor in Accounting and Finance at Accounting Department, College of Business Studies, The Public Authority for Applied Education and Training (Kuwait). He holds a bachelor's degree in Accounting from Kuwait University, 
a Master's Degree in Accounting from New Mexico State University, U.S.A and Diploma in Research in Accounting and Finance from University of Dundee, U.K. His research interests include Emerging stock markets, Trading Rules and Financial reporting. E-mail: Dr.almujamed@ gmail.com. Corresponding author.

Suzanne G. Fifield, PhD: Obtained his doctorate from the University of Dundee (UK). She is Senior Lecturer in Finance in the School of Business at University of Dundee. Her research interests include Emerging stock markets; International finance. E-mail: s.g.m.fifield@dundee.ac.uk

David M. Power, PhD: Obtained his doctorate from the University of Dundee (UK). He is Professor of Business Finance in the School of Business at University of Dundee. His research interests include Capital markets; Stock market anomalies; Emerging capital markets. E-mail: d.m.power@dundee.ac.uk

\section{REFERENCES}

1. Abul, B., 2005, Volatility in Kuwait stock exchange, Master thesis, Maastricht school of management, Netherlands.

2. Abumustafa, N., 2007, A review of regulation, opportunity and risk in Gulf cooperation council stock markets: the case of Kuwait, International Research Journal of Finance and Economics 8, 134-146.

3. Al-Abdulqader, K.A., Hannah, G. and Power, D.M., 2007, The appraisal of ordinary shares by Saudi investors, Research in International Business and Finance 21, 69-86.

4. Alexander, S.S., 1964, Price movements in speculative markets: trends on random walks. Industrial Management Review 2, 24-46.

5. Aljoman Centre for Economic Consultancy, 2011, Listed firms on the Kuwait stock exchange, available at: http://aljoman.net/aljomanar/home.aspx, Accessed March 22, 2011).

6. Almujamed H., 2011, Can the use of technical analysis in emerging markets be profitable?: the case of Kuwait, Saarbrücken: VDM Verlag Dr. Mülle.

7. Almujamed, H., Fifield, S. G. M. and Power, D. M., 2010, An investigation of the role of technical analysis in Kuwait, Paper presented at the BAA Conference, Cardiff, April.

8. Alshamali, M., 1989, Weak form efficiency and factors leading to market efficiency in the Kuwait stock market, PhD thesis, University of Loughborough, U.K.

9. Al-Yaqout, A., 2006, The usefulness of quarterly financial reports, $\mathrm{PhD}$ thesis, University of Loughborough, U.K.

10. Arab Monetary Fund, 2010, The performance of Arabian stock markets, Fourth Quarter, 63.

11. Arnold, J. and Moizer, P., 1984, A survey of the methods used by UK investment analysts to appraise investment in ordinary shares, Accounting and Business Research, Summer, 195-207.

12. Arnold, J., Moizer, P. and Noreen, E., 1984, Investment appraisal methods of financial analysts: a comparative study of UK and US practices, International Journal of Accounting, Spring, 1-18.

13. Arnold, G., 2005, Corporate financial management, Harlow: Financial Times Prentice Hall.

14. Barker, R. G., 1999, The role of dividends in valuation models used by analysts and fund managers, European Accounting Review, 8, 195-218.

15. Butler, K. C. and Malaikah, S. J., 1992, Efficiency and inefficiency in thinly traded stock markets: Kuwait and Saudi Arabia, Journal of Banking \& Finance, 16, 197-210.

16. Cornell, B. and Roll, R., 1981, Strategies for pairwise competitions in markets and organizations, Bell Journal of Economics, 12, 201-213.

17. Clatworthy, M. A., 2005, Transnational equity analysis, Chichester, John Wiley \& Sons.

18. Central Bank of Kuwait Bulletins, 2009, Economic reports, quarterly bulletin (several issues 1995-2009)', available at: http://www.cbk.gov.kw/cbkweb/servlet/cbkmain?Action=qtbl\&archive=20090103\&tbl=RQ34, Accessed March 21, 2011.

19. Fama, E. F., 1970, Efficient capital market: A review of theory and empirical work, Journal of Finance, 25, 383-417.

20. Fifield, S., Power, D. and Sinclair, D., 2005, An analysis of trading strategies in Eleven European stock markets, The European Journal of Finance, 11, 531-548. 
21. KSE, 2011. Several bulletins from Kuwait stock exchange. Available: http://kuwaitse.com/PORTAL/A/KSE/Broker.aspx, Accessed March 23. 2011.

22. Lorie, J. H., Dodd, P. and Hamilton, M., 1998, The stock market, Illinois, Homewood: Dow Jones-Irwin, $2^{\text {nd }}$ Edition.

23. Lovell-Green, N. J., Affleck-Graves, J. F. and Money, A.H., 1986, A survey of investment appraisal methods used by financial analysts in South Africa, The Investment Analysts Journal, November, 7-19.

24. Pike, R., Meerjanseen, J. and Chadwick, L., 1993, The appraisal of ordinary shares by investment analysts in the UK and Germany, Accounting and Business Research, 23, 489-499.

25. Tijjani, B., Fifield, S.G.M. and Power, D.M., 2009, The appraisal of equity investments by Nigerian investors. Qualitative Research in Financial Markets, 1, 6 - 26.

26. Middleton, C. A. J., Fifield, S.G.M., Power, D.M., 2007, Investment in central and eastern European equities: an investigation of the practices and viewpoints of practitioners, Studies in Economics and Finance, 24, 13-31.

27. Mobius, M., 2008, Emerging economies have not lost their appeal: English. Financial Times, 21/10/2008.

28. Naser, K., Nuseibeh, R., and Al-Hussaini, A., 2003, Users' perception of various aspects of Kuwaiti corporate reporting, Managerial Auditing Journal, 18, 599-617.

29. Organization of the Petroleum Exporting Countries, 2009, OPEC annual statistical bulletin, Available: http://www.opec.org/opec_web/static files_project/media/downloads/publications/ASB2009.pdf, Accessed March 22, 2011.

30. Standard and Poor's, 2009, Global stock market factbook.

31. Wang, I., Haslam, J. and Marston, C., 2007, The appraisal of ordinary shares by financial analysts in China, Paper presented at the BAA Conference, London, April.

32. $\mathrm{Xu}, \mathrm{D} ., 2010$, An empirical investigation of weak-form efficiency in the Chinese stock market, PhD Thesis, University of Dundee, UK. 